\title{
ENERGY YIELD GENERATED BY A SMALL BUILDING INTEGRATED PHOTOVOLTAIC INSTALLATION
}

\begin{abstract}
In the recent years photovoltaic (PV) industry has experienced a major growth, caused by the ever present annual decrease in module production prices and the expanding awareness of the general public in terms of renewable energy. There are numerous ways to implement PV modules as an additional energy source for a building, be it mounted on the rooftop, or building integrated (BIPV). An analysis of BIPV consisting of 8 modules with the power of $250 \mathrm{~W}_{\mathrm{p}}$ each was carried out for the building of the Chemistry Faculty of Gdansk University of Technology (GUT). It included monthly irradiance and energy generation values and compared them to data obtained by the means of PV-GIS system, after inserting site specific coordinates. Additional research on the same type of a single module with the power of $270 \mathrm{~W}_{\mathrm{p}}$ was conducted to provide more insight in this matter. A comprehensible analysis allows for defining a final conclusion for the decrease in energy yield for GUT BIPV installation. Data outputs are lower than expected based on PV-GIS values, as for the most time the facade mounted PV system experiences partial soft shading from the nearby park. Furthermore, it is not located directly facing south, but rather south-east which does not prompt ideal working conditions.
\end{abstract}

Keywords: building integrated photovoltaic installation, energy yield, optimal tilt angle, shadowing

\section{Introduction}

The ever growing demand for energy and reduction of $\mathrm{CO}_{2}$ emissions has lead to rapid growth of renewable energy sector. Photovoltaics (PV) is expected to play a significant role in world electricity production, with its power generation oscillating between 2-3 US cents per $\mathrm{kWh}$ [1]. In Europe the supply for electricity is predicted to reach 3,566 TWh in year 2030, which can be covered by increasing the overall energy input from alternative energy sources to $65 \%$ [2].

Building integrated photovoltaics (BIPV) is a promising source of green energy experiencing rapid development, as it exhibits a number of practical advantages, outside of its most important function of energy generation. First of all, it does not reduce the available ground area, which can be otherwise landscaped [3]. Additionally, PV modules may substitute architectural elements and materials used for such building components, e.g. for external walls, rooftops, windows, blinds or shutters [4]. By choosing BIPV the overall cost of front elevation materials is lessened [5]. Finally, PV installation mounted on the building facade provides extra heat, as the side effect of solar irradiance absorption [6].

Mass production for BIPV purposes includes such commodities:

- $\quad$ standard modules,

\footnotetext{
${ }^{1}$ Department of Chemical Apparatus and Theory of Machines, Faculty of Chemistry, Gdansk University of Technology, ul. G. Narutowicza 11/12, 80-233 Gdańsk, Poland, phone +48 583471874

*Corresponding author: ewa.klugmann-radziemska@pg.edu.pl
} 
- frameless modules,

- glass modules,

- modules with enhanced resistance to marine salt,

- $\quad$ PV roof tiles.

\section{Criteria for BIPV design part}

Regardless of project scale, BIPV implementation rests upon finding optimal solution to fully utilize solar radiation for given localization. First and foremost, each building integrated installation ought to be designed in such a way to maximize electric energy production. This, however, depends on location intended for specific installation, namely latitude and azimuth [7]. The optimal module tilt angle to the ground surface for maximum energy yield corresponds to latitude, so the further away it is from the Equator, the higher angle values are, which corresponds to the relationship in Figure 1.

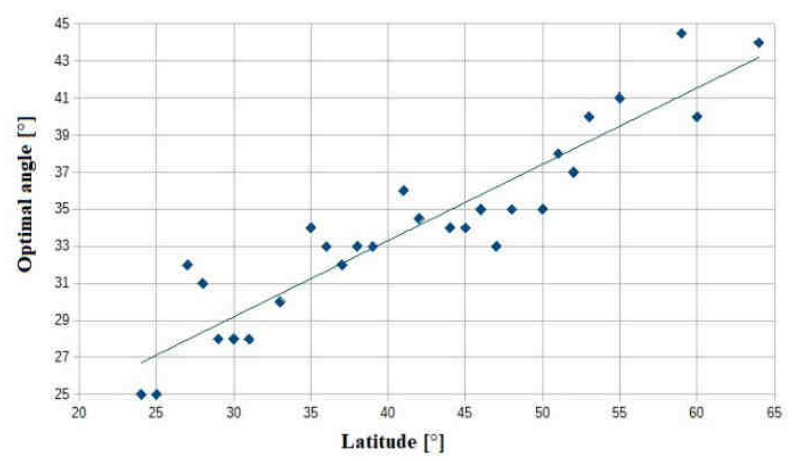

Fig. 1. Optimal tilt angle for PV installation as a function of latitude (on the basis of [8])

Moreover, shadowing factor should also be taken into consideration during design part, as it reduces amount of irradiance reaching solar cells and consequently decreases energy generation [9]. Other buildings in the area, construction elements or trees might shade the PV installation partially or completely, depending on the daytime and season. Several possible ways of PV installation integration are presented in Figure 2.

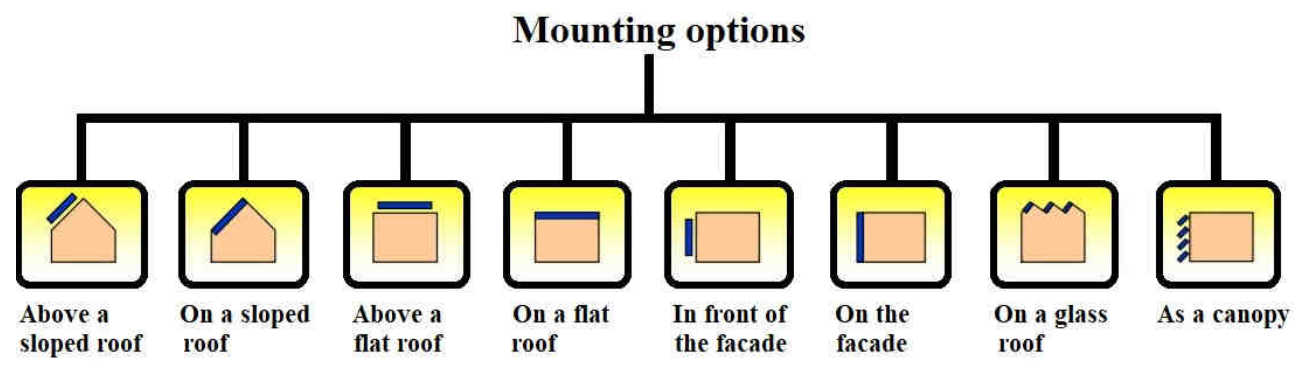

Fig. 2. Possible mounting of BIPV installation [10] 


\section{Facade mounted BIPV system}

The photovoltaic installation able to generate power of $2 \mathrm{~kW}_{\mathrm{p}}$ (kilowatt-peak) at Standard Test Conditions is integrated with south-east facade of the Chemistry C building of Gdansk University of Technology, defined by its geographical coordinates $54.37{ }^{\circ} \mathrm{N}$ and $18.62{ }^{\circ} \mathrm{E}$. It comprises of 8 frameless monocrystalline silicon glass-glass modules BEM-250 manufactured by the company Bruk-Bet Solar, covering the total area of $12.89 \mathrm{~m}^{2}$. A single module is expected to generate maximum power of $250 \mathrm{~W}_{\mathrm{p}}$ and the efficiency provided by the producer reaches $15.51 \%$.

A full technical specification of such module is given in Table 1. It also contains values for monocrystalline silicon glass-glass BEM-270, which was used in field conditions experiment discussed in more detail further in this article. Figure 3 presents current-voltage characteristics for different solar irradiation values for both modules, BEM-250 and BEM-270.

Table 1

Electrical and physical properties of a single monocrystalline photovoltaic modules: BEM-250 and BEM-270

\begin{tabular}{|c|c|c|}
\hline & BEM-250 & BEM-270 \\
\hline Electrical properties & Value & Value \\
\hline Maximum power, $P_{\max }\left[\mathrm{W}_{\mathrm{p}}\right]$ & 250 & 270 \\
\hline Short circuit current, $I_{S C}[\mathrm{~A}]$ & 9.20 & 3.42 \\
\hline Open circuit voltage, $V_{O C}[\mathrm{~V}]$ & 38.80 & 9.00 \\
\hline Maximum power current, $I_{\max }[\mathrm{A}]$ & 8.80 & 30.00 \\
\hline Maximum power voltage, $V_{\max }[\mathrm{V}]$ & 28.45 & 16.90 \\
\hline Module efficiency $[\%]$ & 15.51 & $0+4.99$ \\
\hline Power tolerance $\left[\mathrm{W}_{\mathrm{p}}\right]$ & $0+4.99$ & -0.30 \\
\hline Temperature coefficient voltage $\left[\% /{ }^{\circ} \mathrm{C}\right]$ & -0.31 & -0.40 \\
\hline Temperature coefficient power $\left[\% /{ }^{\circ} \mathrm{C}\right]$ & -0.39 & Value \\
\hline Physical properties & Value & 54 \\
\hline Number of solar cells & 54 & Monocrystalline \\
\hline Type & Monocrystalline & $1634 \times 986 \times 8$ \\
\hline Dimensions $[\mathrm{mm}]$ & $1634 \times 986 \times 8$ & 27 \\
\hline Mass $[\mathrm{kg}]$ & 27 & IP67 \\
\hline Junction box & IP67 & 5 \\
\hline Number of busbars & 3 & \\
\hline
\end{tabular}
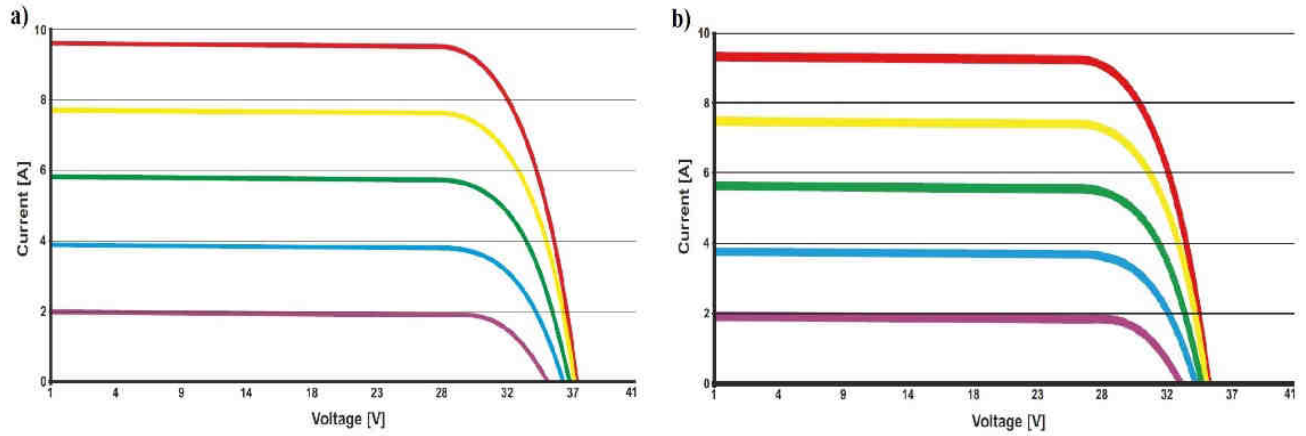

Fig. 3. Current-voltage characteristics at $1000 \mathrm{~W} / \mathrm{m}^{2}$ (red colour), $800 \mathrm{~W} / \mathrm{m}^{2}$ (yellow colour), $600 \mathrm{~W} / \mathrm{m}^{2}$ (green colour), $400 \mathrm{~W} / \mathrm{m}^{2}$ (blue colour) and $200 \mathrm{~W} / \mathrm{m}^{2}$ (violet colour) of solar irradiation intensity for PV module: a) BEM-250, b) BEM-270 
Each photovoltaic module is connected to a single-phase inverter Fronius Galvo 2.0-1 with maximum DC current $17.8 \mathrm{~A}$ and maximum permitted PV generator power of $4.0 \mathrm{~kW}_{\mathrm{p}}$. The maximum efficiency of Galvo 2.0-1 inverter amounts to $96.0 \%$ and European standard efficiency - to $94.9 \%$. Table 2 contains technical data provided by the inverter producer.

Table 2

Technical parameters of output, input data and general information of a Fronius Galvo 2.0-1 inverter

\begin{tabular}{|c|c|}
\hline Input data & Value \\
\hline Maximum input current, $I_{D C \max }[\mathrm{A}]$ & 17.8 \\
\hline Maximum short circuit current of module array $[\mathrm{A}]$ & 26.8 \\
\hline Input voltage range, $V_{D C \text { start }}[\mathrm{V}]$ & $120-420$ \\
\hline Starting point voltage $[\mathrm{V}]$ & 140 \\
\hline Useful voltage range $[\mathrm{V}]$ & $120-335$ \\
\hline Maximum generator power $\left[\mathrm{kW}_{\mathrm{p}}\right]$ & 4.0 \\
\hline Number of direct current connections & 3 \\
\hline Number of MPP trackers & 0 \\
\hline Output data & Value \\
\hline Power rating of alternating current $[\mathrm{W}]$ & 2000 \\
\hline Maximum output power [VA] & 2000 \\
\hline Output AC current, $I_{\mathrm{AC}}[\mathrm{A}]$ & 8.7 \\
\hline Mains connection (voltage range) & 1-NPE $230(+17 \% /-20 \%)$ \\
\hline Frequency (frequency range) $[\mathrm{Hz}]$ & $50 / 60(45-65)$ \\
\hline Total harmonic distortion [\%] & $<4$ \\
\hline Power factor $\left(\cos \varphi_{A C, \tau}\right)$ & $0.85-1.00$ \\
\hline General information & Value \\
\hline Dimensions $[\mathrm{mm}]$ & $645 \times 431 \times 204$ \\
\hline Mass $[\mathrm{kg}]$ & 16.4 \\
\hline Protection level & IP 65 \\
\hline Protection class & 1 \\
\hline Overvoltage category & $2 / 3$ \\
\hline Power consumption at night $[\mathrm{W}]$ & $<1$ \\
\hline Ambient temperature range $\left[{ }^{\circ} \mathrm{C}\right]$ & -25 to +50 \\
\hline Permitted air humidity [\%] & $0-100$ \\
\hline Maximum elevation above sea level [m] & $2,000 / 3,000$ \\
\hline
\end{tabular}

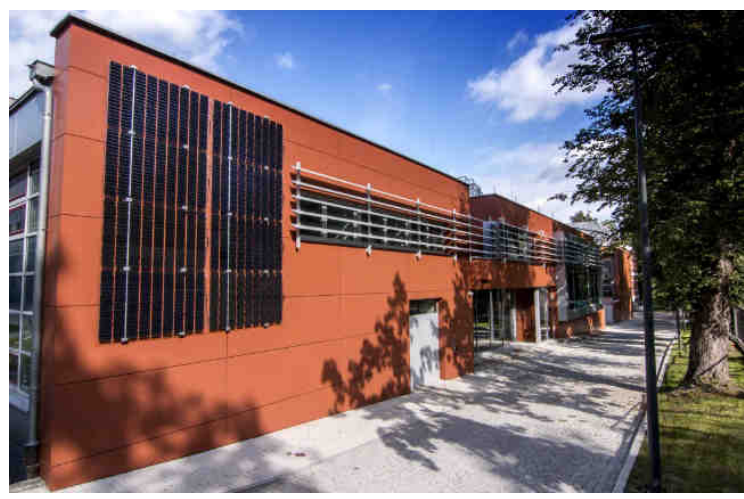

Fig. 4. View of the whole BIPV system on the south-east building facade 
As seen in Figure 4 that includes the view of whole installation, a partial shading effect is expected to appear, due to the fact that the BIPV installation is located in a close distance to a park surrounding the whole university campus. Moreover, because modules are not facing directly south, some decrease in generated power should be expected. Additionally, there is a discrepancy between ambient temperature and module surface temperature. Sensors connected to PV installation measure both values and record it in reports. It has been observed that module temperature is higher than ambient temperature by a few Celsius degrees from September 2018 to February 2019, and by more than $10{ }^{\circ} \mathrm{C}$ in March and following months.

\section{Methodology}

The scope of this research includes such factors as values of solar irradiation measured by the sensor on a facade, generated energy and power obtained by using the Fronius measuring software, as well as reference data collected from Photovoltaic Geographical Information System (PV-GIS) [8]. Values are automatically saved in the Fronius application that allows for a real-time insight. Figure 5 shows the preview of the application homepage.

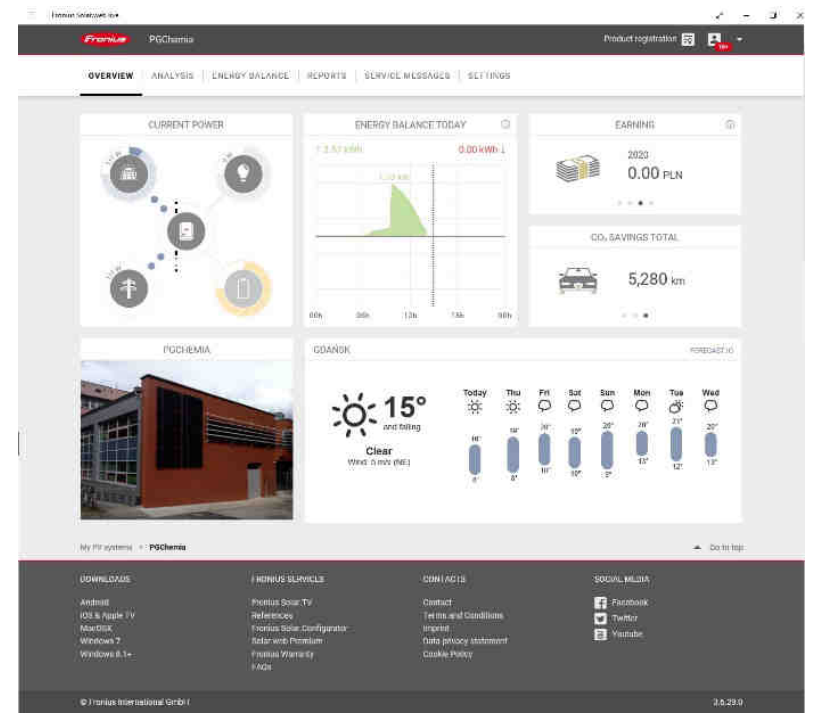

Fig. 5. Homepage for Fronius application software

The monitoring system consists of ambient temperature, module temperature, solar irradiance and solar irradiation sensors. Additionally, current and voltage measurements are taken on both sides of BIPV installation - for direct current (DC) and alternating current (AC). Taking the before mentioned data into account, software provided by Fronius company allows for generating daily, weekly and monthly reports. 


\section{PV-GIS}

Photovoltaic geographic information system is an online site that allows for accurate both on-grid and off-grid PV installation parameters calculation, such as monthly, daily and hourly irradiation and energy output data. In this analysis PVGIS-CMSAF database was applied, as well as calculated horizon option for the usage of terrain shadows. Based on the exact location for a planned PV system, together with azimuth and tilt angle, its solar cell type, installed peak power, estimated system losses and an information whether it would be at fixed-angle or equipped with tracking system PV-GIS estimates such irradiation values:

- $\quad$ clear-sky irradiance $\left[\mathrm{W} / \mathrm{m}^{2}\right]$,

- global irradiance $\left[\mathrm{W} / \mathrm{m}^{2}\right]$,

- $\quad$ direct irradiance $\left[\mathrm{W} / \mathrm{m}^{2}\right]$,

- diffuse irradiance $\left[\mathrm{W} / \mathrm{m}^{2}\right]$,

- global horizontal irradiation $\left[\mathrm{kWh} / \mathrm{m}^{2}\right]$,

- global irradiation at optimum angle $\left[\mathrm{kWh} / \mathrm{m}^{2}\right]$,

- global irradiation at specific angle $\left[\mathrm{kWh} / \mathrm{m}^{2}\right]$,

- $\quad$ diffuse to global irradiation ratio [-],

- direct normal irradiation $\left[\mathrm{kWh} / \mathrm{m}^{2}\right]$.

\section{External measurement}

Similar module as BEM-250, namely BEM-270 frameless glass-glass monocrystalline silicon module manufactured by the company Bruk-Bet Solar, was tested outdoors for a better understanding of external conditions on the energy yield. In order to carry out measurements required to plot current-voltage characteristic a movable test stand with adjustable tilt angle was built, in accordance to the scheme in Figure 6a. BEM-270 module was situated in the same way as BIPV installation, facing south-east and at $90^{\circ}$ tilt angle. Irradiance value was measured by placing pyranometer in few evenly distributed point on the solar module surface. Figure $6 \mathrm{~b}$ pictures the whole test stand with mounted module.

a)

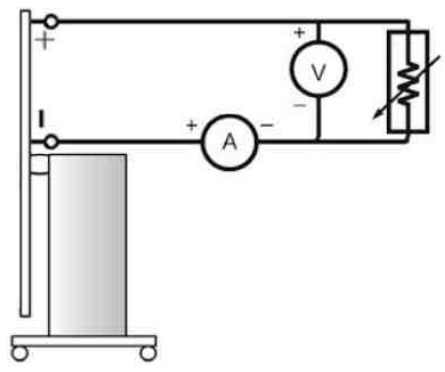

b)

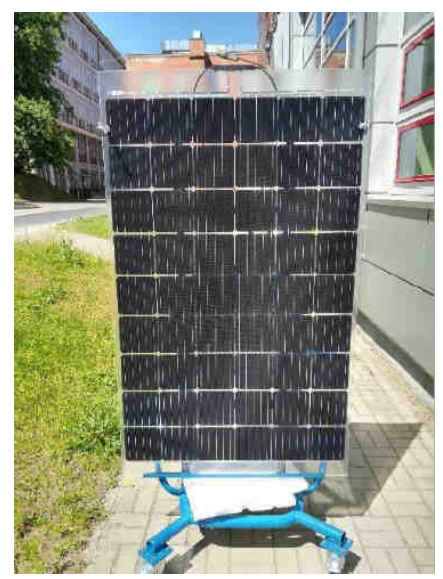

Fig. 6. a) Scheme of the measuring unit, b) whole appearance of workstation built for BEM-270 module 


\section{Calculations}

Monthly reports generated for the whole year from September 2018 to August 2019 by the means of Fronius software helped to obtain irradiation, DC and AC current, DC and AC voltage values. Those were later presented in the form of comparison charts with PV-GIS generated data for this specific $2 \mathrm{~kW}_{\mathrm{p}}$ BIPV installation located at $54.37{ }^{\circ} \mathrm{N}$ and $18.62{ }^{\circ} \mathrm{E}$ and facing south-east direction vertically, which corresponds to $-70^{\circ}$ azimuth in PV-GIS system.

Relative difference in irradiation and energy generation values for the whole installation area are calculated in accordance with formula (1) and (2) respectively:

$$
\begin{gathered}
G_{R}=\frac{G-G_{F}}{G} \cdot S \cdot 100 \% \\
E_{R}=\frac{E-E_{F}}{E} \cdot 100 \%
\end{gathered}
$$

where: $G_{R}$ - relative difference between irradiation value for Fronius software and PV-GIS system [\%], $G$ - irradiation value for a given month obtained from PV-GIS system $\left[\mathrm{kWh} / \mathrm{m}^{2}\right], G_{F}$ - irradiation value for a given month obtained from Fronius software $\left[\mathrm{kWh} / \mathrm{m}^{2}\right], S$ - total area of photovoltaic installation $\left[\mathrm{m}^{2}\right], E_{R}$ - relative difference between generated energy value for Fronius software and PV-GIS system [\%], $E$ - energy generated value for a given month obtained from PV-GIS system [kWh], $E_{F}$ - energy generated value for a given month obtained from Fronius software [kWh].

The efficiency of BIPV installation is calculated by using formula (3):

$$
\eta=\frac{E_{F}}{G_{F} \cdot S} \cdot 100 \%
$$

where: $\eta$ - photovoltaic installation efficiency [\%], $E_{F}$ - energy generated value for a given month obtained from Fronius software $[\mathrm{kWh}], G_{F}$ - irradiation value for a given month obtained from Fronius software $\left[\mathrm{kWh} / \mathrm{m}^{2}\right], S$ - total area of photovoltaic installation $\left[\mathrm{m}^{2}\right]$.

Monthly DC to AC conversion rate is obtained on the basis of formula (4):

$$
\mathrm{CR}=\frac{P_{A C}}{P_{D C}} \cdot 100 \%
$$

where: $C R$ - conversion rate [\%], $P_{D C}$ - direct current value for a given month obtained from Fronius software $[\mathrm{W}], P_{A C}$ - alternating current value for a given month obtained from Fronius software [W].

\section{Results and discussion}

Figures 7 and 8 represent monthly values of energy that comes from solar irradiation and PV generated energy, respectively. They and compare data obtained from Fronius software for $2 \mathrm{~kW}_{\mathrm{p}}$ installation integrated with Chemistry building of Gdansk University of Technology and information from PV-GIS system after plotting coordinates and specifications of the testes system, and are calculated for the whole installation area, that is $12.89 \mathrm{~m}^{2}$. The results show that both solar irradiation and energy yield are higher in PV-GIS. However, the overall course of irradiation and energy yield steady growth from winter to spring and then the decrease of those two factors in autumn months is also observed for the real-time installation, as predicted by PV-GIS. Similar relationship has 
been observed for a $15.5 \mathrm{~kW}_{\mathrm{p}}$ installation in Bialystok, which was located on the rooftop of a detached building [11]. The only deviation from the trend set by PV-GIS occurs from May to August, where there are noticeable changes between values for neighbouring months.

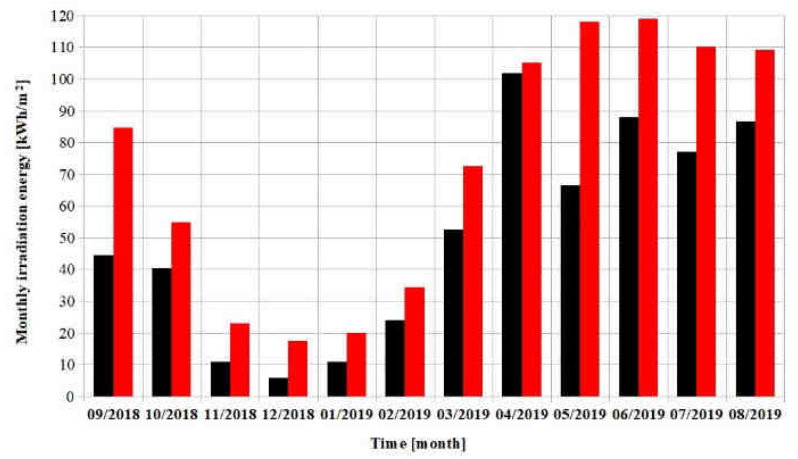

Fig. 7. Monthly irradiation values obtained from Fronius software (black colour) and PV-GIS system (red colour)

Such mismatch between Fronius and PV-GIS values could be explained by the fact of locating the installation next to the park. Soft shadowing caused by the leaves limits the amount or solar irradiation reaching solar cells, which translates to lowered energy yield, as presented in Figure 8. The highest generated energy was observed in month April with the value of almost $114 \mathrm{kWh}$. However, other months exhibit much lower values, in the range of 50-100 kWh in the Summer, and way below $20 \mathrm{kWh}$ for Winter.

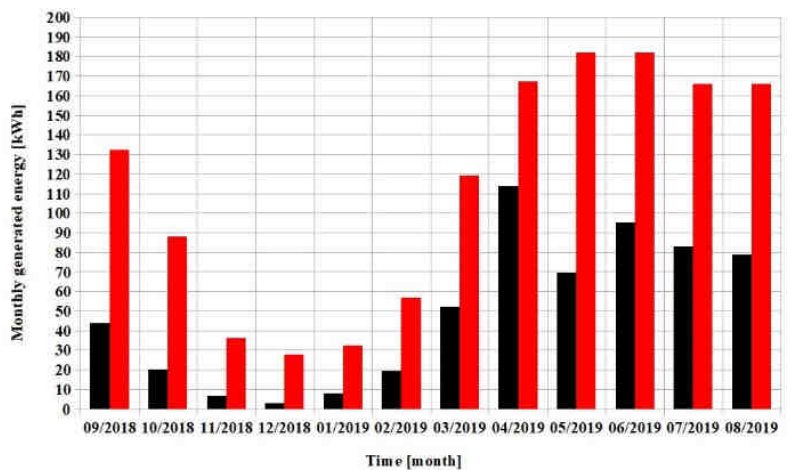

Fig. 8. Monthly energy generation values obtained from Fronius software (black colour) and PV-GIS system (red colour)

Significant difference rates between data acquired from Fronius software and PV-GIS system has been observed and are presented in Figure 9. The relative difference is the biggest for autumn and winter period, with irradiation difference above $60 \%$ for time period from November to January and energy generation difference exceeding $70 \%$ for months from September to February. The lowest difference ratio is observed for April in 
both, irradiation $\left(G_{R}=3.0 \%\right)$ and energy yield $\left(E_{R}=31.9 \%\right)$. This is the month in which the highest number for solar irradiation $\left(G_{F}=101.8 \mathrm{kWh} / \mathrm{m}^{2}\right)$ and produced energy $\left(E_{F}=113.8 \mathrm{kWh}\right)$ has been noted.

Interesting discussion concerning the effect of external factors on working parameters of PV modules was conducted by the research group at AGH University of Science and Technology, Krakow, Poland. They've highlighted the issue of non-uniform temperature distribution, which means some solar cells heat up to higher values, thus impacting negatively energy yield of the whole installation [12]. Such outcome may be even more enhanced if the system has poor cooling conditions. In the case of PV installation at GUT in Gdansk the front part is adequately chilled by wind, however the backside is closely moved against the building facade and most likely faces restricted heat flow. The negative impact of high temperatures has been linked to an overall PV module efficiency [13].

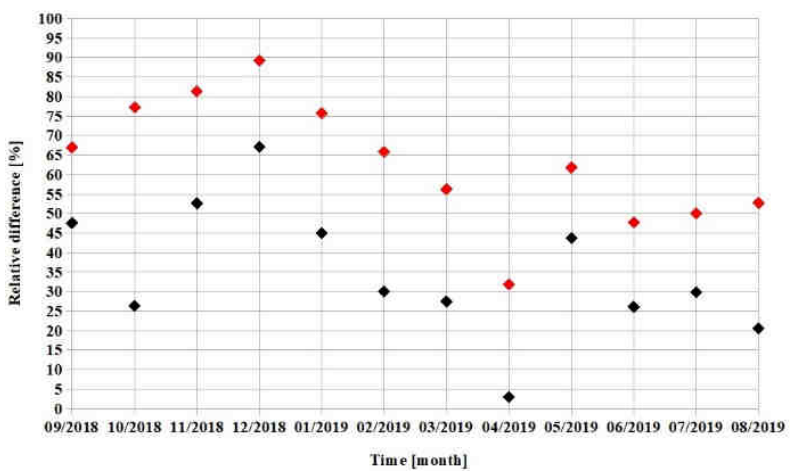

Fig. 9. Relative difference between irradiation energy (black colour) and energy generation (red colour) values obtained from Fronius software and PV-GIS system

The flow of both functions, for irradiation and energy generation, is similar. Relative difference reaches the lowest values in spring and summer, which could indicate its dependence on environmental conditions and additional module shading from trees. Table 3 contains efficiency values for the whole year.

Table 3

Efficiency $\eta$ of BIPV installation based on BEM-250 modules

\begin{tabular}{|c|c|c|c|c|c|c|c|c|c|c|c|c|}
\hline Month & I & II & III & IV & V & VI & VII & VIII & IX & X & XI & XII \\
\hline $\boldsymbol{\eta}$ [\%] & 6.2 & 7.7 & 8.7 & 8.1 & 8.4 & 8.3 & 7.0 & 7.6 & 3.9 & 4.8 & 4.0 & 5.6 \\
\hline
\end{tabular}

The biggest efficiency values fall within spring and summer period, however they never exceed $9 \%$. This would mean that there is a considerable discrepancy between $15.51 \%$ efficiency given by the manufacturer and the actual annual efficiency of $6.7 \%$. Additionally, lower efficiency values for some months could be caused by the accumulation of soil on the PV module surface [14].

Annual DC to AC conversion rate analysis for Fronius Galvo 2.0-1 inverter is plotted as a function of time in Figure 10. Power conversion rate on average lays in the range between 70 and $80 \%$, with the exception in October $(C R=66.8 \%)$ and November 
$(C R=62.2 \%)$. DC to AC conversion rate is noticeable lower than the maximum efficiency given by the inverter manufacturer.

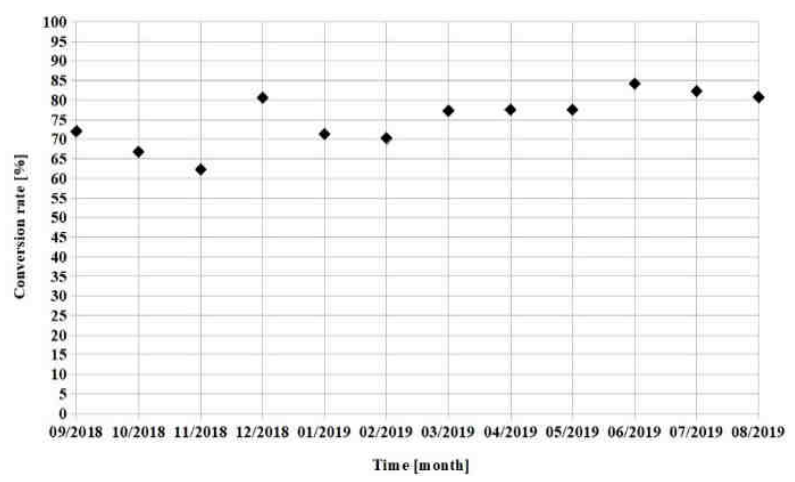

Fig. 10. DC to AC power generation conversion rate

\section{BEM-270 measurements}

Experimental analysis carried out for BEM-270 module manufactured by the same producer responsible for manufacturing BEM-250 modules for BIPV installation provided more insight in the low values of irradiation, energy yield and power in comparison with PV-GIS system. Figures 11 and 12 contain current-voltage and power-voltage characteristics respectively that were measured under irradiance $632 \mathrm{~W} / \mathrm{m}^{2}$ for two different conditions, without shade and with natural shade from the nearby tree covering one third of the module.

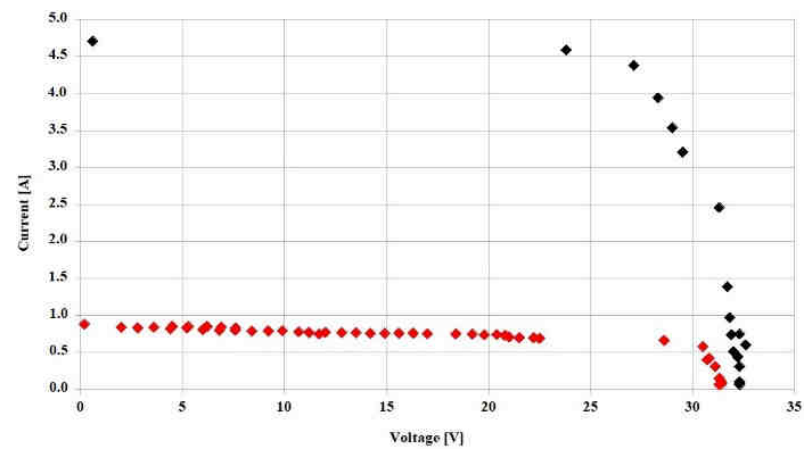

Fig. 11. Current-voltage characteristic at $632 \mathrm{~W} / \mathrm{m}^{2}$ irradiance without shade (black colour) and with natural shade (red colour)

Maximum power point power measured for a vertical position and on a clear-sky day reached $139.4 \mathrm{~W}$, however after partially shading the module in one third of its area it dropped to $18.9 \mathrm{~W}$, displaying the $86.4 \%$ difference in maximum generated power. 


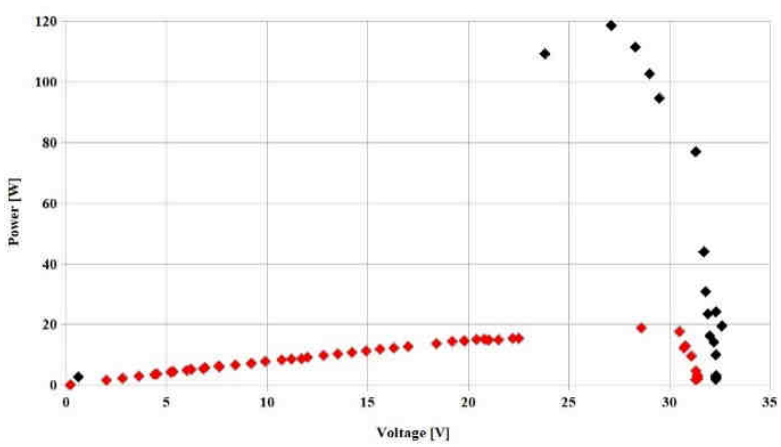

Fig. 12. Power-voltage characteristic at $632 \mathrm{~W} / \mathrm{m}^{2}$ irradiance without shade (black colour) and with natural shade (red colour)

The maximum power yield observed for the BEM-270 module corresponds to efficiency value $1.9 \%$ for a shaded module and $11.7 \%$ without any shade covering the module. Such results give a difference of $31 \%$ between efficiency, between data observed in real clear-sky conditions and $15 \%$ efficiency stated by the manufacturer for $600 \mathrm{~W} / \mathrm{m}^{2}$. BEM-250 however exhibits higher differences reaching $48 \%$ for month March to August, and $65 \%$ for the rest of the year. This relationship clearly suggests that the working conditions are more optimal for spring and summer, although in those months there is a factor of soft shading that impacts the efficiency negatively.

\section{Conclusion}

This work focuses on analysing annual irradiation, energy yield and generated power data that corresponds to the BIPV installation mounted on the building facade facing south-east, precisely $54.37^{\circ} \mathrm{N}$ and $18.62{ }^{\circ} \mathrm{E}$. Comparing those values to the ones provided by PV-GIS system has proven considerable disparity between two data sets. Most important aspect that could account for such losses is the lack of placement optimisation, as such system should be facing directly south and be tilted at optimal angle, which is around $35^{\circ}$ for Gdansk. Additionally, there is also a factor of installation shading from the nearby trees that impacts generated power. They are located directly before installation, in 5 meter vicinity, and greatly limit the amount of solar irradiance reaching solar cells. Such plummeting decrease observed between values for Fronius software and PV-GIS system could be explained by the suboptimal placement. Another drawback is the heightened module temperature, especially for Spring and Summer months. It has been stated that it impacts the monthly system efficiency negatively, since PV modules generate more power in lower temperatures. The analysed installation however, does not provide a sufficient heat dissipation, as it is mounted closely to the building facade, thus the back side of each module reaches higher temperatures than their front covers. Final factor adding to the overall diminished energy yield in comparison with PV-GIS prediction is possible soil accumulation on PV module surface. It can build up over the course of months and cover completely some places of installation, which blocks solar energy passing through the glass surface.

Measurements carried out for BEM-270 module placed in the same way as BIPV installation proved that soft shade covering one third of all solar cells in total drastically 
reduces power output, thus resulting in efficiency decrease. Additional analysis should be planned for the future experiments for BEM-270 module tilted at the optimal angle and facing directly south.

Authors of this work highlight the importance of taking real environmental effects into account during BIPV constructing part. Designing functional PV system cannot rely solely on a module's data sheet and manufacturer specifications, but rather should take a broad approach, recognizing the value of every factor - azimuth, tilt angle, additional shading and area specific whether conditions.

\section{References}

[1] Schmela M. SolarPower Europe. Global Market Outlook for Solar Power 2019-2023. Belgium: SolarPower Europe; 2019. ISBN: 9789082714326. Available from: https://www.solarpowereurope.org/global-marketoutlook-2019-2023/ (Accessed: 19 April 2019).

[2] Jäger-Waldau A. PV Status Report 2018, EUR 29463 EN. Publications Office of the European Union. Luxembourg; 2018. ISBN: 9789279974656. DOI:10.2760/826496; JRC113626.

[3] Barker M, Blewett-Silcock T, Eising K, Gutschner M, Kjellsson E, Lutter E, et al. Solar Electricity Guide. European Commission. Institut Cerdà, Spain 2001. ISBN: 8890044284.

[4] Norton B, Eames PC, Mallick TK, Huang MJ, McCormack SJ, Mondol JD, et al. Solar Energy. 2011;85:1629-64. DOI: 10.1016/j.solener.2009.10.004.

[5] Li D, Lam T, Chan H, Mak A. Appl Energy. 2009;86:722-9. DOI: 10.1016/j.apenergy.2008.08.009.

[6] Fossa M, Ménézo C, Leonardi E. Exp Therm Fluid Sci. 2008;32:980-90. DOI: 10.1016/j.expthermflusci.2007.11.004.

[7] Yun GY, Steemers K. Solar Energy. 2009;83:69-80. DOI: 10.1016/j.solener.2008.06.007.

[8] Photovoltaic Geographical Information System. Available from: http://re.jrc.ec.europa.eu/pvgis/ (Accessed: 19 April 2019).

[9] Yoon JH, Song J, Lee SJ. Solar Energy. 2011;85:723-33. DOI: 10.1016/j.solener.2010.12.026.

[10] Deutsche Gesellschaft für Sonnenenergie (DGS). Planning and Installing Photovoltaic Systems. A guide for installers, architects and engineers. New York: Routledge; 2008. ISBN: 9781844074426. Available from: https://content.taylorfrancis.com/books/download?dac=C2012-0-00483-

9\&isbn=9781136559877\&format=previewPdf (Accessed: 19 April 2019).

[11] Piotrowska-Woroniak J. Ecol Chem Eng S. 2017;24(4):517-38. DOI: 10.1515/eces-2017-0034.

[12] Jaszczur M, Teneta J, Hassan Q, Majewska E, Hanus R. Heat Transfer Eng. 2019. DOI: 10.1080/01457632.2019.1699306.

[13] Luboń W, Pełka G, Marszałek K, Małek A. Ecol Chem Eng S. 2017;24(4):539-49. DOI: 10.1515/eces-2017-0035.

[14] Jaszczur M, Teneta J, Styszko K, Hassan Q, Burzyńska P, Marcinek E, et al. Environ Sci Pollut Res. 2019;26:8402-17. DOI: 10.1007/s11356-018-1970-x. 